\title{
Influence of Kudumbasree on Women Empowerment - a Study
}

\author{
Dr.K.Venugopalan \\ (Associate Professor, Department of Commerce, Government College Madappally, Kozhikode Dt, Kerala, \\ India)
}

\begin{abstract}
Empowerment of women and their participation in the development process has been considered an essential feature of development. It is presumed that real development is possible only if the women and men work in equal terms. Gender equality and empowerment of women is recognized globally as a key element to achieve progress in all areas. Rural women are regarded as voiceless and defenseless. Raping cases are appearing in the newspapers every day. Even politicians are not supporting them. So they are to be empowered to fight against the evils faced by them. Kudumbasree project was started in Kerala in 1998. Women empowerment is one of the important objectives of Kudumbasree along with poverty eradication. The aim of the Kudumbashree scheme is to improve the standard of living of poor women in rural areas by setting up micro-credit and productive enterprises. It opened a new string of expected events in our development history Kudumbasree is the poverty eradication mission of the state of Kerala. It is a community based self help initiative involving poor women. Kudumbashree was conceived as a joint programme of the Government of Kerala and NABARD implemented through Community Development Societies of Poor Women, serving as the community wing of Local Governments .As per documents associated with Kudumbashree, women want to identify their inner strength, opportunities for growth and their role in reshaping their own destiny. Thirteen years are so far covered by this programme. The main objective of this paper is to know to what extend this programme has influenced the rural women for their empowerment. Kerala is considered as literate state compared with all the states of our country. The study indicates that majority of the members of Kudumbasree units are working on daily wages and their total income is low. The women empowerment has achieved only a limited extend by Kudumbasree members.
\end{abstract}

Key words: Personal skills, Decision making power, self confidence, awareness, women empowerment

\section{Introduction}

Development is the mantra of globalization and liberalisation. Women have an important role in the development process. Empowerment of women and their participation in the development process has been considered an essential feature of development. It is presumed that real development is possible only if the women and men work in equal terms. Gender equality and empowerment of women is recognized globally as a key element to achieve progress in all areas. Jawaharlal Nehru commended "in order to awaken the people, it is the women who has to be awakened first. Once she is on the move, the household moves, the village moves, the country moves and thus we build the India tomorrow" 1 .

But the present position of women in developing and underdeveloped countries is not considered good. Rural women are regarded as voiceless and defenseless. Raping cases are appearing in the newspapers every day. Even politicians are not supporting them. So they are to be empowered to fight against the evils faced by them. There had been intensive efforts in nineties to bring the women-folk, especially those belonging to the weaker sections and poor, who had been economically and socially underprivileged within and outside the family, to the forefront and empower them through specific programmes and thereby empower the entire family and community. Ensuring justice to women was one of the prime objectives of the development agenda of the People's Planning Campaign initiated in 1997. Kudumbashree, a Malayalam coinage, means prosperity of the family. It is an innovative programme of the Government of Kerala introduced for the eradication of absolute poverty in ten years through concerted community action under the leadership of local self governments. Kudumbasree is the poverty eradication mission of the state of Kerala. Kudumbasree project was started in Kerala in 1998. The programme has 37 lakhs members and covers more than $50 \%$ of the households in Kerala ${ }^{2}$. It has built around three vital components, micro credit, entrepreneurship and empowerment. Women empowerment is one of the important objectives of Kudumbasree along with poverty eradication.

The aim of the Kudumbashree scheme is to improve the standard of living of poor women in rural areas by setting up micro-credit and productive enterprises. It is a community based self help initiative involving poor women. Kudumbashree was conceived as a joint programme of the Government of Kerala and NABARD implemented through Community Development Societies (CDSs) of Poor Women, serving as the community wing of Local Governments. The aim of the Kudumbashree scheme is to empower women as a strategy for Poverty Eradication. Empowerment of women and poor women driving their development is a 
powerful strategy to alleviate poverty. The Kudumbashree Community based organizations are acting as social safety nets, increasing access to entitlements and providing avenues for political participation ${ }^{3}$.

\section{Origin of the Research Problem}

Poverty is a serious problem faced by all developing and underdeveloped countries in the modern world. It is felt that the problem of poverty can be solved through a concentrated endeavor by the State. Viable opportunities can be provided to the underprivileged and the destitute by means of lending asset creating facilities. Women households are the cruelest victims of deprivation and destitution. So any poverty eradication programs must aim at improving the standard of living environment along with empowerment of the women communities. Livelihood opportunities are to be provided to women. The micro credit and self help groupings are better sources for improving the standard of living of people. The aim of the Kudumbashree scheme is to improve the standard of living of poor women in rural areas by setting up microcredit and productive enterprises. It opened a new string of expected events in development history. As per documents related to Kudumbashree, women want to identify their inner strength, opportunities for growth and their role in reshaping their own destiny. Kudumbashree aims at the empowerment of women, giving them the central place in the programmes meant for their benefit. The programme aims to empower them through collective action. Gender equality gains (including inclusion of women in education) will help to reduce fertility rates and improve maternal and child health. This process of empowerment should become the signal light to their children, their families and society at $\operatorname{large}^{4}$. Thirteen years are so far covered by this programme. The researcher is interested to know to what extend this programme has influenced the rural women for their empowerment.

\section{Objectives of the Study}

The main objective of the study is to assess whether there is any significant change in empowerment of rural women through Kudumbasree.

\section{Hypothesis for the Study}

1. Kudumbasree makes no significant change in women empowerment.

\subsection{Sub Hypothesis}

1. There is no significant relationship of between acquisition of personal skills and women empowerment.

2. There is no significant relationship of between Decision Making power and women empowerment

3. There is no significant relationship of between self confidence and women empowerment

4. There is no significant relationship of between knowledge and women empowerment

5. There is no significant relationship of between awareness and women empowerment

\section{1 .Collection of Data}

\section{Methodology and Sources of Data}

The influence of Kudumbashree on women is assessed by the field surveys and personal interviews. Statistical evidences are also drawn from the sources available with the Department of Economics and Statistics and the Project Directorate of State Poverty Eradication Mission of the Government of Kerala. Micro-units, under the scheme are surveyed and examined for arriving at conclusions. The study is mainly based on primary data, and the secondary data is used to supplement and support the primary data. A field survey was carried out covering rural areas.

\subsection{Research Population and Sample}

Micro units of Kudumbashree are selected as research population.

\subsection{Sampling Design}

Five micro units of Kudumbashree of Kozhikode district are selected by random sampling method and members of the selected units are the respondents. There are twelve block Panchayaths in Kozhikode district namely Vadakara, Tuneri, Kunnummal, Thodannur, Meladi, Perambra, Balussery, Panthalayani, Chelannor, Koduvally, Kuuamangalam and Kozhikode . Five micro units are selected on random basis from these block Panchayaths. It consists of three units of Vadakara- Deepam (Puduppanam), Harisee ( Chorode) and Peruma (Orkkatteri) units, One unit of Kunnamangalam- Pulari (Mukkam) and one unit of Kunnummal Cheriyakappummel (Maruthonkara), Each unit consists of 20 members. So a total of 100 members of 5 units are taken as sample respondents for the purpose of study. 


\subsection{Method of Data Collection}

All the items shown in the questionnaire is asked to members of the units. They are asked to fill the questionnaire in August - September 2013. Personal interviews are also conducted with office bearers' of Kudumbasree units in the same period. Out of 100 questionnaires served, 90 respondents filled the questionnaire completely and 10 respondents have not filled certain questions and so they are rejected.

\subsection{Data Analysis and Technique}

The general information has been analyzed with the help of primary data collected from among the respondents through structured questionnaires. Likewise, acquisition of personal skills, Decision making power, self confidence, Knowledge and awareness empowerments of the Kudumbasree members have also been analyzed on the basis of primary data.

\subsection{Scaling Techniques}

Scaling technique is used to measure variables related with level of improvement on a three point scale with a weightage of three, two and one for Greatly Improved, Fairly improved and not improved.

\subsection{Tools of Analysis}

Statistical techniques like percentage, mean, standard deviation, $\mathrm{Z}$ test etc are used for analysis for data.

\subsection{Variables used in the Study}

The variables used for study related with empowerment of women consist of

1. Personal skills

2. Decision making power

3. Self confidence

4. Knowledge and

5. Awareness.

\subsection{Women Empowerment}

\section{Operational Definition}

In simple terms we can define empowerment is giving power. Power is the key word of the term empowerment. According to the International Encyclopedia (1999), power means having the capacity and the means to direct one's life towards desired social, political and economic goals or status. Power means control over material assets, intellectual resources and ideology. In Webster's English Dictionary the verb empower means to give the means, ability and authority. Empowerment implies a state of mind and attitude of a person. It is a process through which people or communities increase their control or mastery of their own lives and the decisions that affect their day-to-day life. Women empowerment is any process that provides greater autonomy to women through the sharing of relevant information and provision of control over factors affecting their performance. ${ }^{5}$ Empowerment implies a state of mind and attitude of a person. It is a process through which people or communities increase their control or mastery of their own lives and the decisions that affect their day-to-day life. Awareness is a necessary part of empowerment. Awareness of rights is required for a person to develop his capacity of self-control, self-strength and self-reliance and to build freedom of choice and action. Empowerment is about change, choice and power. It is a process of change by which the individuals and groups with little or no power gain the power and ability to make choices that affect their lives. Women empowerment is a stage of acquiring power for women in order to understand her rights and to perform her responsibilities towards oneself and others in a most effective way ${ }^{6}$.

Acquisition of personal skills, Power to take decisions, knowledge about their rights and privileges, self confidence and Awareness are necessary parts of empowerment. Awareness of rights is required for a person to develop his capacity of self-control, self-strength and self-reliance and to build freedom of choice and action. It is a process of change by which the individuals and groups with little or no power gain the power and ability to make choices that affect their lives. Women empowerment is a process whereby women become able to organize themselves, to increase their own self reliance, to assert their independent right to make choices and to control resources which will assist in challenging and eliminating their own subordination. In this study it refers to empowerment of women especially the women residing in rural areas.

\section{Scope of the Study}

The study is confined to Kudumbasree units of Kerala. Study is conducted on the basis of sample units taken from rural areas of Kozhikode district. 


\section{Review of Literature}

Kudumbasree is a unique poverty eradication mission of the state of Kerala. Many studies have so far conducted in relation with Kudumbasree and self help groups in different parts of our country. A brief view of the studies so far conducted is given below.

Gurumoorthy $(2000)^{7}$ reveals that empowering women contributes to social development. Economic progress in any country whether developed or underdeveloped could be achieved through social development. The self-help group disburses micro-credit to the rural women for the purpose of making them enterprising women and encouraging them to enter into entrepreneurial activities. Credit needs of the rural women are fulfilled totally through the self-help groups. SHGs enhance equality of status of women as participants, decision makers and beneficiaries in the democratic economic, social and cultural spheres of life. SHGs also encourage women to take active part in socio-economic progress of our nation.

Puhazhendhi and Satyasai $(2001)^{8}$ in their study attempted to evaluate the performance of SHGs with special reference to social and economic empowerment. Primary data collected with the help of structured questionnaire from 560 sample households in 223 SHGs functioning in 11 states representing four different regions across the country have formed the basis of the study. The findings of the study reveal that the SHGs as institutional arrangement could positively contribute to the economic and social empowerment of rural poor. The impact on the later is more pronounced than on the former. Though there has been no specific pattern in the performance of SHGs among different regions, the southern region could edge out other regions. The SHGs programme has been found more popular in the southern region and its progress in other regions is quite low, thus signifying an uneven achievement among the regions. Older groups had relatively more positive features like better performance than younger groups.

Sakuntala Narasimhan $(2001)^{9}$, focuses specifically on rural Scheduled Caste and Scheduled Tribe women, who are disadvantaged as women, as members of the rural section of the laypeople and because of their low caste status. The book compares the effectiveness of State initiatives with the motivation - and conscientisation strategy advocated by Action for Welfare and Awakening in Rural Environment (AWARE), a non-governmental development organization working in 6000 villages spread over 7 States in India. It analyses the success of AWARE's work among women through various case studies and concludes that, besides monetary resources, it is the mindset of the policy makers, bureaucrats and particularly the women concerned that must change in order to assist the empowerment of women.

Jaya S. Anand (2002) ${ }^{10}$, in her discussion paper titled "Self-Help Groups in Empowering Women: Case Study of Selected SHGs and NHGs", gives a review of progress of Self Help Groups. She has attempted to examine the performance of selected SHGs and NHGs and to assess its impact, especially the impact of micro credit programme on empowering women. It has been clearly established that delivering credit alone may not produce the desired impact. The supporting services and structures through which credit is delivered, ranging from group formation and training to awareness-raising and a wide range of other supporting measures are critical to make the impact of group activity strong and sustainable.

Meenakshi Malhotra (2004) $)^{11}$, in her work entitled, "Empowerment of Women" (in 3 volumes), deals with the issues leading to empowerment of women with particular reference to rural women. Volume one deals with issues like gender inequalities in labour market and in entrepreneurship. Volume two focuses on micro finance options for women empowerment. It looks into micro credit schemes for rural women and micro finance movement in India. Third volume describes the various programmes introduced to empower women and bring them into the orbit of development network.

J. Bhagyalakshmi (2004) $)^{12}$, in the article, "Women's Empowerment - Miles to Go", points out that India as a signatory to the UN Convention has taken several measures to ensure full development and advancement of women. The women specific programmes are showing positive results in empowering women, until now, one feels, there are miles to go and promises to keep. All forms of violence against women, physical and mental, whether at familial or communal level shall be dealt with great care. She states that all forms of discrimination against girl child and violation of her rights shall be eliminated by undertaking strong measures both preventive and disciplinary within and outside the family. Though women play a major role in agriculture and allied sectors, their contribution is hardly recognized. Intensive efforts are needed to ensure that benefits of training, extension and various programmes will reach them to make them more effective in their own area of operation.

Sri.V.P.Ragavan $(2009)^{13}$, in his article stated that the poor women of the State have become active participants in the planning and implementation process of various ant-poverty programmes. By participating in various income generating -cum-developmental activities, the morale and confidence of women became very high. Capacity of the poor women of the State in several areas has gone up considerably. Status of women in families and community has also improved. Kudumbashree has gained national and international acclaim as an ideal and workable model of participatory development for eradicating poverty. He further stated that women empowerment is the best strategy for poverty eradication. 
Minimol M. C and Makesh K. G (2012) ${ }^{14}$ in their study identified that Intellectual empowerment is considered more important, or at least equally important to social, economic or financial empowerment. The concept of personal empowerment often fails to encompass intellectual empowerment. The objective intended to be achieved is that the members become more capacitated to think and act better from blunt in thinking to sharp; and from thick in action to fine. According to them the concept of SHGs for rural women empowerment has not yet run its full course in attaining its objective.

Sanjay Kanti Das (2012) ${ }^{15}$ in his study indicated that SHG-Bank Linkage of micro finance programme has a profound influence on the economic status, decision making power, knowledge and self worthiness of women participants of SHG linkage programme in Assam.

Kenneth Kalyani, Seena P.C $(2012)^{16}$ reveals that economic development is the base for other development. Collective effort has been recognized as tenets of women empowerment. Through women empowerment leads to sustainable social development. Economic development of women leads to better living status in the family, educational, nutritional, and the health needs of the children were well satisfied. Economic independence through Kudumbasree improved the social participation of its members and the Kudumbashree NHG movement is supporting for social empowerment of poor women flock.

Now it is apparent that a number of studies are conducted on SHG groups and Kudumbasree and its role on empowerment of women. The researcher is intended to study to know to what extend Kudumbasree programme in Kerala has influenced the rural women for their empowerment.

\section{Data Analysis}

The entire analysis is divided into two parts such as Part A and Part B .Part A shows the profile of respondents. Part B indicates analysis related with women empowerment.

9.1.Part A

Table No :1

Demographic Features of Kudumbasree Members

\begin{tabular}{|c|c|c|c|c|c|c|c|c|c|c|c|c|c|}
\hline \multirow[t]{2}{*}{ Variable } & \multirow[t]{2}{*}{ Response Categories } & \multicolumn{2}{|c|}{ Pulari } & \multicolumn{2}{|c|}{ Deepam } & \multicolumn{2}{|c|}{$\begin{array}{c}\text { Cheriya- } \\
\text { kappummel }\end{array}$} & \multicolumn{2}{|c|}{ Harisree } & \multicolumn{2}{|c|}{ Peruma } & \multicolumn{2}{|c|}{ Total } \\
\hline & & No. & $\%$ & No. & $\%$ & No. & $\%$ & No. & $\%$ & No. & $\%$ & No. & $\%$ \\
\hline \multirow{4}{*}{$\begin{array}{l}\text { Age } \\
\text { group }\end{array}$} & \multirow{4}{*}{\begin{tabular}{|l}
$18-30$ \\
$30-40$ \\
Above 40 \\
Total
\end{tabular}} & 5 & 28 & 5 & 29 & 8 & 44 & 8 & 42 & 7 & 39 & 33 & 37 \\
\hline & & 12 & 67 & 9 & 53 & 5 & 28 & 6 & 32 & 6 & 33 & 38 & 42 \\
\hline & & 1 & 5 & 3 & 18 & 5 & 28 & 5 & 26 & 5 & 28 & 19 & 21 \\
\hline & & 18 & 100 & 17 & 100 & 18 & 100 & 19 & 100 & 18 & 100 & 90 & 100 \\
\hline \multirow{7}{*}{$\begin{array}{l}\text { Occup- } \\
\text { ation }\end{array}$} & \multirow{7}{*}{$\begin{array}{l}\text { Cooli } \\
\text { Private Sector } \\
\text { Govt } \\
\text { Semi Govt } \\
\text { Others } \\
\text { No job } \\
\\
\text { Total }\end{array}$} & 5 & 28 & 9 & 53 & 14 & 78 & 5 & 26 & 4 & 22 & 37 & 41 \\
\hline & & 5 & 28 & - & - & - & - & - & - & 4 & 22 & 9 & 10 \\
\hline & & - & - & - & - & - & - & - & - & 2 & 11 & 2 & 2 \\
\hline & & - & - & - & - & - & 0 & 2 & 11 & - & - & 2 & 2 \\
\hline & & 2 & 11 & 3 & 18 & 2 & 11 & 5 & 26 & 3 & 17 & 17 & 19 \\
\hline & & 6 & 33 & 5 & 29 & 2 & 11 & 7 & 37 & 5 & 28 & 23 & 26 \\
\hline & & 18 & 100 & 17 & 100 & 18 & 100 & 19 & 100 & 18 & 100 & 90 & 100 \\
\hline \multirow[t]{6}{*}{ Income } & \multirow{6}{*}{$\begin{array}{l}\text { Below Rs } 10,000 \\
10,000-20,000 \\
20,000-30,000 \\
30,000-40,000 \\
\text { Above } 40,000 \\
\text { Total }\end{array}$} & 18 & 100 & 15 & 88 & 9 & 50 & - & - & 13 & 72 & 55 & 61 \\
\hline & & & & - & - & 7 & 39 & 13 & 68 & 5 & 28 & 25 & 28 \\
\hline & & & & - & - & - & - & 6 & 32 & - & & 6 & 7 \\
\hline & & & & 2 & 12 & - & - & - & - & - & & 2 & 2 \\
\hline & & & & - & - & 2 & 11 & - & - & - & & 2 & 2 \\
\hline & & 18 & 100 & 17 & 100 & 18 & 100 & 19 & 100 & 18 & 100 & 90 & 100 \\
\hline \multirow{5}{*}{$\begin{array}{l}\text { Educat- } \\
\text { ion }\end{array}$} & \multirow{5}{*}{$\begin{array}{l}\text { Up to VIII th } \\
\text { VIII to X } \\
\text { Plus2/PreDegree } \\
\text { Graduate } \\
\text { Other } \quad \text { Total }\end{array}$} & 2 & 11 & 3 & 18 & 5 & 28 & 4 & 21 & - & - & 14 & 16 \\
\hline & & 5 & 28 & 9 & 53 & 9 & 50 & 8 & 42 & 7 & 39 & 38 & 42 \\
\hline & & 9 & 50 & 3 & 18 & 2 & 11 & 6 & 32 & 7 & 39 & 27 & 30 \\
\hline & & $\begin{array}{l}2 \\
-\end{array}$ & 11 & $\begin{array}{l}2 \\
-\end{array}$ & 11 & 2 & 11 & 1 & 5 & 4 & 22 & 11 & 12 \\
\hline & & 18 & 100 & 17 & 100 & 18 & 100 & 19 & 100 & 18 & 100 & 90 & 100 \\
\hline
\end{tabular}

Source: Survey Data

Five micro units namely Pulari (Mukkam), Deepam (Puduppanam), Cheriyakappummel (Maruthonkara), Harisee (Chorode) and Peruma (Orkkatteri) units of Kozhikode district are taken for study. Each unit consists of 20 members.42 percentage of members belongs to the age group of 30 to 40 and 37 percentage of rural women belongs to the age group of 18 to 30 . The occupation of nearly 44 percent of respondents is cooli. 23 percent of respondents have no job. They are housewives. $46 \%$ of members in Kudumbasree units are earning less than Rs 10,000 in a year. Only $2 \%$ of members have income more than Rs 40,000 . 


\subsection{Part B. Women Empowerment}

Women Empowerment is basically the creation of an environment where women can make independent decisions on their personal development as well as shine as equals in society. The researcher intends to analyze the empowerment achieved by women in Kerala through Kudumbasree activities so far performed.

Table No: 2

Acquisition of Personal Skills

\begin{tabular}{|c|c|c|c|c|c|c|c|c|c|c|c|c|c|}
\hline \multirow{3}{*}{$\begin{array}{l}\text { Sl. } \\
\text { No }\end{array}$} & \multirow[t]{3}{*}{ Factors } & \multicolumn{9}{|c|}{ Levels of improvement } & & & \\
\hline & & \multicolumn{3}{|c|}{ Greatly improved } & \multicolumn{3}{|c|}{ Fairly improved } & \multicolumn{3}{|c|}{ Not improved } & \multicolumn{3}{|c|}{ Total } \\
\hline & & $\mathrm{R}$ & $\%$ & $\mathrm{~S}$ & $\mathrm{R}$ & $\%$ & $\mathrm{~S}$ & $\mathrm{R}$ & $\%$ & $\mathrm{~S}$ & $\mathrm{R}$ & $\%$ & TS \\
\hline 1. & Ability to face difficulties & 56 & 62.22 & 168 & 30 & 33.33 & 60 & 4 & 4.45 & 4 & 90 & 100 & 232 \\
\hline 2. & $\begin{array}{l}\text { Ability to negotiate and } \\
\text { bargain }\end{array}$ & 48 & 53.33 & 144 & 38 & 42.22 & 76 & 4 & 4.45 & 4 & 90 & 100 & 224 \\
\hline 3. & $\begin{array}{l}\text { Ability to face personal } \\
\text { and official problems }\end{array}$ & 54 & 60 & 162 & 26 & 28.89 & 52 & 10 & 11.11 & 10 & 90 & 100 & 224 \\
\hline 4. & $\begin{array}{l}\text { Ability to participate in } \\
\text { parents teachers } \\
\text { Association of schools/ } \\
\text { Colleges }\end{array}$ & 62 & 68.89 & 186 & 8 & 8.89 & 16 & 20 & 22.22 & 20 & 90 & 100 & 222 \\
\hline 5. & $\begin{array}{l}\text { Ability to speak and speak } \\
\text { out }\end{array}$ & 68 & 75.56 & 204 & 10 & 11.11 & 20 & 12 & 13.33 & 12 & 90 & 100 & 236 \\
\hline
\end{tabular}

Source: Primary Data

R- Respondents, S- Score

Table No: 3

Decision making Power

\begin{tabular}{|c|c|c|c|c|c|c|c|c|c|c|c|c|c|}
\hline Sl. & \multirow[t]{3}{*}{ Factors } & \multicolumn{9}{|c|}{ Levels of improvement } & & & \\
\hline & & \multicolumn{3}{|c|}{ Greatly improved } & \multicolumn{3}{|c|}{ Fairly improved } & \multicolumn{3}{|c|}{ Not improved } & \multicolumn{3}{|c|}{ Total } \\
\hline & & $\mathrm{R}$ & $\%$ & $\mathrm{~S}$ & $\mathrm{R}$ & $\%$ & $\mathrm{~S}$ & $\mathrm{R}$ & $\%$ & $\mathrm{~S}$ & $\mathrm{R}$ & $\%$ & TS \\
\hline 1. & In Household affairs & 70 & 77.78 & 210 & 14 & 15.55 & 28 & 6 & 6.67 & 6 & 90 & 100 & 244 \\
\hline 2. & In education of children & 74 & 82.22 & 222 & 8 & 8.89 & 16 & 8 & 8.89 & 8 & 90 & 100 & 246 \\
\hline 3. & To purchase household articles & 72 & 80 & 216 & 10 & 11.11 & 20 & 8 & 8.89 & 8 & 90 & 100 & 244 \\
\hline 4. & In self matters & 62 & 68.89 & 186 & 22 & 24.44 & 44 & 6 & 6.67 & 6 & 90 & 100 & 236 \\
\hline
\end{tabular}

Source: Primary data

Table No: 4

Self Confidence

\begin{tabular}{|c|c|c|c|c|c|c|c|c|c|c|c|c|c|}
\hline \multirow{3}{*}{$\begin{array}{l}\text { S1.N } \\
\text { o }\end{array}$} & \multirow[t]{3}{*}{ Factors } & \multicolumn{9}{|c|}{ Levels of improvement } & & & \\
\hline & & \multicolumn{3}{|c|}{ Greatly improved } & \multicolumn{3}{|c|}{ Fairly improved } & \multicolumn{3}{|c|}{ Not improved } & \multicolumn{3}{|c|}{ Total } \\
\hline & & $\mathrm{R}$ & $\%$ & $\mathrm{~S}$ & $\mathrm{R}$ & $\%$ & $\mathrm{~S}$ & $\mathrm{R}$ & $\%$ & $S$ & $\mathrm{R}$ & $\%$ & $\mathrm{TS}$ \\
\hline 1. & $\begin{array}{l}\text { Ability to face critical } \\
\text { situations }\end{array}$ & 62 & 68.89 & 186 & 18 & 20 & 36 & 10 & 11.11 & 10 & 90 & 100 & 232 \\
\hline 2. & $\begin{array}{l}\text { Ability to participate } \\
\text { Gramasabha }\end{array}$ & 64 & 71.11 & 192 & 8 & 8.89 & 16 & 18 & 20 & 18 & 90 & 100 & 226 \\
\hline 3. & $\begin{array}{l}\text { Ability to participate and } \\
\text { talk in PTA meetings }\end{array}$ & 44 & 48.89 & 132 & 14 & 15.56 & 28 & 32 & 35.55 & 32 & 90 & 100 & 192 \\
\hline 4. & $\begin{array}{l}\text { To go for shopping without } \\
\text { the help of family members }\end{array}$ & 58 & 64.44 & 174 & 8 & 8.89 & 16 & 24 & 26.67 & 24 & 90 & 100 & 214 \\
\hline
\end{tabular}

Source: Primary Data

Table No: 5

Knowledge

\begin{tabular}{|c|c|c|c|c|c|c|c|c|c|c|c|c|c|}
\hline Sl. & \multirow[t]{3}{*}{ Factors } & \multicolumn{9}{|c|}{ Levels of improvement } & & & \\
\hline & & \multicolumn{3}{|c|}{ Greatly improved } & \multicolumn{3}{|c|}{ Fairly improved } & \multicolumn{3}{|c|}{ Not improved } & \multicolumn{3}{|c|}{ Total } \\
\hline & & $\mathrm{R}$ & $\%$ & $\mathrm{~S}$ & $\mathrm{R}$ & $\%$ & $\mathrm{~S}$ & $\mathrm{R}$ & $\%$ & $\mathrm{~S}$ & $\mathrm{R}$ & $\%$ & TS \\
\hline 2. & $\begin{array}{l}\text { Deals with banks and } \\
\text { banking transactions }\end{array}$ & 64 & 71.11 & 192 & 16 & 17.78 & 32 & 10 & 11.11 & 10 & 90 & 100 & 234 \\
\hline 3. & Involvement in politics & 28 & 31.11 & 84 & 14 & 15.56 & 28 & 48 & 53.33 & 48 & 90 & 100 & 160 \\
\hline 5. & About rights of women & 50 & 55.56 & 150 & 30 & 33.33 & 60 & 10 & 11.11 & 10 & 90 & 100 & 220 \\
\hline
\end{tabular}


Source: Primary Data

Table No: 2 shows Personal skills acquired by members after joining in Kudumbasree. 62 percent of the respondents greatly improved the ability to face difficulties, 53 percent of them greatly improved to negotiate and bargain. Likewise there is a great improvement in ability to participate in Parent's Teachers Association of schools/ Colleges (69 percent), ability to face personal and official problems (60 percent) and ability to speak and speak out (76 percent).

Table No: 3 indicates the decision making power of respondents after joining in Kudumbasree. There is a great improvement in decision power in household affairs ( 78 percent) in education of children ( 82 percent), to purchase household articles ( 80 percent) and in self matters. (69 percent).

Table No: 4 indicates self confidence attained after joining in Kudumbasree. There is a great improvement in ability to face critical situations (69 percent), ability to participate in gramasabhas (71 percent) and to go for shopping without the help of family members (58 percent). But 36 percent of the respondents mentioned that the ability to participate and talk in PTA and public meeting is not improved after joining in Kudumbasree

Table No: 5 reveals that knowledge in toto has not greatly improved after joining in Kudumbasree. Great improvement has happened in the case of ability to handle finance (72 percent) and to deal with banks and banking transactions (71\%) compared with other factors. 53 percent of respondents have less knowledge about politics and 38 percent are not aware about government projects.

Table No: 6

Awareness

\begin{tabular}{|c|c|c|c|c|c|c|c|c|c|c|c|c|c|}
\hline \multirow{3}{*}{$\begin{array}{l}\text { Sl. } \\
\text { No }\end{array}$} & \multirow[t]{3}{*}{ Factors } & \multicolumn{9}{|c|}{ Levels of improvement } & & & \\
\hline & & \multicolumn{3}{|c|}{ Greatly improved } & \multicolumn{3}{|c|}{ Fairly improved } & \multicolumn{3}{|c|}{ Not improved } & \multicolumn{3}{|c|}{ Total } \\
\hline & & $\mathrm{R}$ & $\%$ & $\mathrm{~S}$ & $\mathrm{R}$ & $\%$ & $\mathrm{~S}$ & $\mathrm{R}$ & $\%$ & $\mathrm{~S}$ & $\mathrm{R}$ & $\%$ & TS \\
\hline 1. & Nutrition & 69 & 76.67 & 207 & 19 & 21.11 & 38 & 2 & 2.22 & 2 & 90 & 100 & 247 \\
\hline 2. & Dangers of using pesticides & 54 & 60 & 162 & 24 & 26.67 & 48 & 12 & 13.33 & 12 & 90 & 100 & 222 \\
\hline 3. & Use of liquors and its effects & 45 & 50 & 135 & 22 & 24.44 & 44 & 23 & 25.56 & 23 & 90 & 100 & 202 \\
\hline 4. & Seasonal diseases & 37 & 41.11 & 111 & 35 & 38.89 & 70 & 18 & 20 & 18 & 90 & 100 & 199 \\
\hline
\end{tabular}

Source: Primary Data

Table No: 6 shows that 77 percent of respondents have great awareness about the need for nutrition, 60 percent have great awareness about dangers in using pesticides, and 50 percent have great awareness about the use of liquors and its effects. The awareness about seasonal diseases has fairly improved in the case of 39 percent of respondents.

\subsubsection{Study Results}

We notice that the orientations of the sample individuals regarding the statements are positive as their means are higher than the significant value which is 2 except in the cases of statements 16 and 17 .

The mean and standard deviation of the statements given to sample respondents are described below.

\begin{tabular}{|c|c|c|c|c|}
\hline Factors & & Statements & Mean & Std Dev \\
\hline \multirow{5}{*}{$\begin{array}{l}\text { Acquisition of personal } \\
\text { skills }\end{array}$} & 1. & Ability to face difficulties & 2.58 & 0.576 \\
\hline & 2. & Ability to negotiate and bargain & 2.49 & 0.582 \\
\hline & 3. & Ability to face personal and official problems & 2.49 & 0.687 \\
\hline & 4. & $\begin{array}{l}\text { Ability to participate in parents teachers Association of } \\
\text { schools/ Colleges }\end{array}$ & 2.47 & 0.833 \\
\hline & 5. & Ability to speak and speak out & 2.62 & 0.708 \\
\hline \multirow{4}{*}{ Decision making power } & 6. & In Household affairs & 2.71 & 0.582 \\
\hline & 7. & In education of children & 2.73 & 0.611 \\
\hline & 8. & To purchase household articles & 2.71 & 0.619 \\
\hline & 9. & In self matters & 2.62 & 0.607 \\
\hline \multirow{4}{*}{$\begin{array}{c}\text { Self confidence } \\
.\end{array}$} & 10. & Ability to face critical situations & 2.58 & 0.683 \\
\hline & 11 & Ability to participate Gramasabha & 2.51 & 0.806 \\
\hline & 12 & Ability to participate and talk in PTA meetings & 2.13 & 0.909 \\
\hline & 13 & To go for shopping without the help of family members & 2.38 & 0.877 \\
\hline \multirow{4}{*}{ Knowledge } & 14 & Ability to handle finance & 2.71 & 0.619 \\
\hline & 15 & Deals with banks and banking transactions & 2.60 & 0.679 \\
\hline & 16 & Involvement in politics & 1.78 & 0.892 \\
\hline & 17 & About Govt projects & 1.96 & 0.842 \\
\hline
\end{tabular}


Influence of Kudumbasree on Women Empowerment - a Study

\begin{tabular}{|l|l|l|c|c|}
\hline & 18 & About rights of women & 2.44 & 0.685 \\
\hline \multirow{4}{*}{ Awareness } & 19 & Nutrition & 0.484 & 2.74 \\
\cline { 2 - 5 } & 20 & Dangers of using pesticides & 2.47 & 0.718 \\
\cline { 2 - 5 } & 21 & Use of liquors and its effects & 0.834 & 2.24 \\
\cline { 2 - 5 } & 22 & Seasonal diseases & 2.21 & 0.753 \\
\hline
\end{tabular}

Table No. 7

Women Empowerment

\begin{tabular}{|c|c|c|l|l|l|c|}
\hline & Factors & Mean & $\begin{array}{l}\text { Std } \\
\text { Dev }\end{array}$ & $\begin{array}{l}\text { Std } \\
\text { Error }\end{array}$ & $\begin{array}{l}\text { Z } \\
\text { Value }\end{array}$ & Rank \\
\hline 1. & Acquisition of Personal Skills & 2.53 & 0.617 & 0.06504 & 1.076 & 2 \\
\hline 2. & Decision making Power & 2.69 & 0.606 & 0.0639 & 3.60 & 1 \\
\hline 3. & Self Confidence & 2.40 & 0.848 & 0.0894 & 0.895 & 4 \\
\hline 4. & Knowledge & 2.29 & 0.835 & 0.0880 & 1.82 & 5 \\
\hline 5. & Awareness & 2.41 & 0.741 & 0.0781 & 0.640 & 3 \\
\hline 6. & Grand mean & 2.45 & 0.761 & \multicolumn{2}{|l}{} \\
\cline { 1 - 3 } & \multicolumn{2}{|r|}{} & &
\end{tabular}

The moderate value of levels of improvement on acquisition of personal skills on the basis of total scales of all five factors is 2.53 . The factors like ability to face difficulties (2.58) and ability to speak and speak out (2.62) are above moderate value but factors like ability to negotiate and bargain (2.49), ability to face personal and official problems (2.49), and ability to participate in parent's teachers association of schools/colleges (2.47) are less than the moderate value. On the basis of the analysis it is found that there is an average level of improvement in the acquisition of personal skills by way of participating in Kudumbasree.

The moderate value of levels of improvement on decision making power on the basis of total scales of all four factors is 2.69.Decsion making power in self matters (2.62) is less than the moderate value, but all other factors mean is higher than the moderate value. The study indicates that decision making power of women is greatly improved after joining in Kudumbasree.

The moderate value of levels of improvement in self confidence on the basis of four factors is 2. 40 . Ability to face critical situations (2.58), Ability to participate gramasabhas (2.51) is more than the moderate value but other factors like Ability to participate and talk in PTA meetings (2.13) and to go for shopping without the help of family members (2.38) are less than moderate value. Hence it is found that the improvement in self confidence is achieved on a moderate basis.

The moderate value of Knowledge acquisition after joining Kudumbasree is 2.29. Ability to handle finance (2.71) and deal with banks and banking transactions (2.6) are greater than the moderate value. But all other three factors like Involvement in Politics (1.78), knowledge about government projects(1.96), knowledge about rights of women (2.44) are less than moderate value. Hence, it is found that the Acquisition of knowledge after joining in Kudumbasree is less than moderate value.

The moderate value related with the factor awareness is 2.41 . The value of factor awareness about nutrition is higher than the moderate value (2.74), and the value of awareness about dangers of using pesticides (2.47) is near to moderate value and the factors value is less than moderate value. It is found that there is a moderate level of awareness about the factors.

By considering all factors of women empowerment it is found that the moderate value is 2.45 . The average value of two factors namely acquisition of personal skills and decision making power is greater than the moderate value. But all others factors value is less than the moderate value. Hence by considering majority factors it is found that women empowerment after joining Kudumbasree has attained only a low level basis.

\subsubsection{Testing of Hypothesis}

At $5 \%$ level of significance the critical value of $\mathrm{z}$ test is \pm 1.96 . The hypothesis related to statements numbered 2 is rejected. It indicates that there is significant relationship between Decision making power and women empowerment. At the same time the hypothesis fixed related to statements 1, 3, 4and 5 are accepted. That means factors like acquisition of personal skills, self confidence, Knowledge and awareness of Kudumbasree members has not achieved as a contributing factor for women empowerment.

\section{Summary and Findings}

Kudumbasree is the poverty eradication mission of the state of Kerala. It is a community based self help initiative involving poor women. It was launched formally by the Government of Kerala on $17^{\text {th }}$ May 1998 . It is launched by the Government of Kerala for wiping out absolute poverty from the state through concerted community action under the leadership of Local Self Government. Kudumbashree is a Malayalam word which means prosperity of the family. The programme has 37 lakhs members and covers more than $50 \%$ of the 
households in Kerala. It has built around three vital components, micro credit, entrepreneurship and empowerment.

The researcher studied the influence of Kudumbasree on the rural women for their empowerment. For the purpose of study five micro units of Kudumbashree of Kozhikode district are selected by random sampling method and members of the selected units are the respondents. There are twelve block Panchayaths in Kozhikode district namely Vadakara, Tuneri, Kunnummal, Thodannur, Meladi, Perambra, Balussery, Panthalayani, Chelannor, Koduvally, Kuuamangalam and Kozhikode . Five micro units are selected on random basis from these block Panchayaths. It consists of three units of Vadakara- Deepam (Puduppanam), Harisee ( Chorode) and Peruma (Orkkatteri) units, One unit of Kunnamangalam- Pulari (Mukkam) and one unit of Kunnummal - Cheriyakappummel (Maruthonkara), Each unit consists of 20 members. So a total of 100 members of 5 units are taken as sample respondents for the purpose of study. Personal interviews are also to be conducted with office bearers' of Kudumbasree units in the same period. Out of 100 questionnaires served, 90 respondents filled the questionnaire completely and 10 respondents have not filled certain questions and so they are rejected. A scaling technique is used to measure variables related with level of improvement on a three point scale with a weightage of three, two and one for Greatly Improved, Fairly improved and not improved.

The following are the major findings of the study.

1. Majority of them are working on daily wages.

2. Less than 50 percent of the members are earning income less than Rs 10,000.

3. Nearly forty two percent of respondents have 8 to $10^{\text {th }}$ qualification.

4. Decision making power of Kudumbasree members have greatly improved after joining in Kudumbasree.

5. Self confidence has been improved.

6. Personal skills of members have greatly improved

7. Knowledge has not improved

8. Awareness about need for nutrition, dangers of using pesticides, use of liquors and its affects has been increased.

9. Factors like acquisition of personal skills, self confidence, knowledge and awareness has not achieved as a contributing factor for women empowerment.

\section{Recommendations}

The researcher put forward the following suggestions to enhance women empowerment

1. Proper information should be given to Kudumbasree members to know about the aim and objectives of Kudumbasree. For this purpose anganawadi teachers can be used.

2. Entrepreneur development programme should be started and proper training should be given to members in this respect. Commerce teachers who are working in higher secondary schools and colleges can be utilized for providing training.

3. Active participation of Kudumbasree members in gramasabhas is to be insisted.

4. The members should take active involvement in different activities including politics.

\section{Conclusion}

The study has provided an insight on women empowerment acquired by Kudumbasree members after joining in the Kudumbasree. Majority of the members of Kudumbasree are women workers who are working on daily wages. Decision making power, Personal skills, and awareness of the members are improved except self confidence and knowledge. By considering other factors such as self confidence and knowledge, we can conclude that women empowerment has not achieved to the fullest extent. Women workers should give due consideration for developing self confidence and knowledge about intellectual rights. Each unit of Kudumbasree must give attention to the various factors for the empowerment of members.

\section{References}

[1] Kochurani, Joseph, Women Empowerment a Conceptual Analysis (Vimala Books and Publications, Kanjirappally, 2005).

[2] Government of Kerala, (1999-2000), Kudumbashree Project: State Poverty Eradication Mission, Annual Report 1999-2000, (Local Self Government Department, Thiruvananthapuram, Kerala, India).

[3] Suneetha Kadiyala, Scaling up Kudumbashree Collective Action for Poverty Alleviation and women's Empowerment, International Food Policy Research Institute, U.S.A. May 2004

[4] Nidheesh K B, Rural Women's Empowerment Is the Best Strategy for Poverty Eradication in Rural Areas, International Journal of Rural studies, Vol 15 No 2 Oct 2008

[5] K. Sayulu, G. Sardar \& B. Sridevi, Impact of Self-Help Groups on Women Empowerment- An Empirical Study, Management Researcher, XI No.3 \& 4, January - June 2005.

[6] Ruby, J A ,Microfinance and women empowerment: a study of Kudumbasree Project in Kerala, doctoral diss., MG university, Kottayam, 2013

[7] R. Gurumoorthy, Self-help groups empower rural women, Kurukshetra, vol.48, no.5 (2000), 22.

[8] V. Puhazhendhi and K.J.S. Satyasai, Economic and social empowerment of rural poor through SHG's., Indian Journal of Agricultural Economics, vol. 56, no.3 (2001),362. 
[9] Sakuntala, Narasimhan, Empowering Women, an Alternative Strategy from Rural India (New Delhi, Sage Publications India Pvt. Ltd, 1999).

[10] Anand, Jaya S, Self-Help Groups in Empowering Women: A Study of selected SHGs and NHGs in Kerala, KKRPLLD, Centre for Development Studies, Trivandrum, Kerala, India,1999.

[11] Meenakshi Malhotra, Empowerment of Women (In Three Volumes (Delhi, Isha Books, 2004).

[12] J. Bhagyalakashmi, Women's Empowerment - Miles to Go, Yojana, 48 No.8, August 2004, 38-41.

[13] V P Raghavan, Micro-credit and Empowerment: a study of Kudumbashree Projects in Kerala, India, Journal of Rural Development, Vol. 28, No. (4), NIRD, Hyderabad.2009, Pp 478-479.

[14] Minimol M. C and Makesh K. G, Empowering rural women in Kerala: A study on the role of Self Help Groups (SHGs) International Journal of Sociology and Anthropology Vol. 4(9), November, 2012, 270-280,

[15] Sanjay Kanti Das, Socio-Economic Empowerment of Women through SHG-Banking Linkage Programme: A Boon for Development; International Journal of Management and Business Studies; Vol. 2, Issue 1, Jan. - March 2012

[16] Kenneth Kalyani, Seena P.C, Socio-economic Changes of Women through Kudumbasree- A Study from Puthenvelikkara (Gp) of Kerala State, India , International Research Journal of Social Sciences, Vol. 1(2), 1-7, October (2012)

[17] http://www.kudumbashree.org 